\title{
Exploring Factors Affecting the Development of Export-Oriented Garment Industry: Facing the Global Competitiveness Challenges
}

\author{
Yan Zeng ${ }^{1}$ \\ ${ }^{1}$ School of Management, Guangxi University of Foreign Languages, Nanning, China \\ Correspondence: Yan Zeng, School of Management, Guangxi University of Foreign Languages, Nanning, 19 \\ Wuhe Avenue Qingxiu District, China.
}

Received: March 18, 2020

Accepted: April 17, $2020 \quad$ Online Published: May 8, 2020

doi:10.5539/ibr.v13n6p20

URL: https://doi.org/10.5539/ibr.v13n6p20

\begin{abstract}
The purpose of this study was to explore the factors that affect the development of exported-oriented garment industry facing the global competitiveness challenges.This study examines competitiveness challenges of export-oriented garment industry by testing the research hypotheses.The basis of this study lies in understanding what kind of competitiveness challenges in terms of resource-based, dynamic capabilities and market-based factors. In this study, a purposeful sample of 250 sectors was drawn from total 359 Thailand exported-oriented garment sectors and a total of 211 respondents fully answered the required questions. Study participants were garment supervisors and managers, in garment industry over 5 years. The data collection includes questionnaire investigation for quantitative factor analysis method. Specifically, this study provides empirical evidence on the specific channels and mechanisms through what principal factor within current garment sectors. The findings showed the factors influence the competitiveness challenges of export-oriented garment industry. Therefore, the competitiveness challenges conceptual model emerged with respect to this industry.The model, which identified the main competitive hurdles that export-oriented garment industry faces (i.e., challenges relates to productivity, lead-time, collaboration, opportunity identification, quick response and risk identification factors). Additionally, the author presents Tai export-oriented garment industry current situation, which revealed this strong buy-driven industry needs to restructure their strategies to focus high value added activities and to enhance their competitiveness.
\end{abstract}

Keywords: competitiveness challenges, export-oriented garment industry, Thailand

\section{Introduction}

As an export dependent economy, the economy of Thailand may be at a turning point, the manufacturers are at risk of losing their competitive niche. Meanwhile, garment industry is one of the oldest and largest export industries, which has greatly contributed to economy in Thailand. However, this industry was facing significant decline in export over the last couple of years. The competitive challenges that originate from changes of competitive environment in the global markets have posed at the export-oriented garment (EOG) industry, are issues from crucial concern for this industry. According the data of world-bank, the garment export value of Thailand has been declined to begin to 2012, the steepest decline was seen from fell by $0.62 \% 2014,7.31 \%$ in 2015, down 8.76\% in 2016. By contrast, its competitor in ASEAN for this industry, in Vietnam, the clothing export increases $11.2 \%$ in 2015.

According to the problem explained above, the following three research questions were used to guide the inquiry in order to gain additional insights and understanding into the changes.

RSQ1.From the EOG industry perspective, what resource-based factors influence export-oriented garment sector's competitiveness?

RSQ2.What types of capabilities that are demanded by the EOG industry?

RSQ3.How does the EOG industry to confirm the market-based factors and overcome the risk?

\section{Literature Review}

Reviewing literature with industrial competitiveness related models, and identifying the interactions among the firm's resources, dynamic capabilities, market risk and agile supply chain. 


\subsection{Industry's Competitiveness Theories}

In the literature we can find numerous findings focused on the industry's competitiveness challenges. The use of industry's competitiveness theories in this study are importance as a framework for assessing the competitive advantages (Kozlenkova et al., 2014). There are just three main theories relate to this study including resource-based view, dynamic capability and market-based view, which need to evaluated to better understand the competitiveness challenges of EOG industry. Based on those theory and extant study that investigated the relationship between the principle factors of industrial competitiveness and the following factors were proposed by researcher for this study. Firstly, the productivity and shorten lead-time were identified as principal factors in resource-based view. Traditionally, labor and capital have been confirmed as main factors that determine production output (Chan \& Mountain, 1983). Scholars believed that the effect of productivity was regarded as important factor to account for the industrial competitiveness which traditional input factors have limited impact (Vlachvei \& Notta, 2017). Meanwhile, lead time was considered as principle factor because a lot of export-oriented garment sectors successfully improved their competitiveness through the lead-time reduction. This approach facilitates the garment to make rapid response within the global value chain. Owing to this point, the productivity and shorten lead-time attribute to the industrial competitiveness. Secondly, the collaboration and opportunity identification were emphasized to be critical factors in dynamic capabilities due to their advantage in export-oriented garment industry. Matopoulos, et al. (2007) state that the higher levels of collaboration is essential factor to achieve competitiveness in export-oriented garment industry. The collaboration among actors in global value chain is the important factor for managing a value chain in the export-oriented sector (Curwen et al., 2013). Due to customer's requirement, timely and accurate deliveries, have also forced the industry to move toward collaboration. Concerning the opportunity identification in global market, although there is much debate surrounding the definition, the opportunity identification capability is considered fundamental factor for industrial competitiveness (Muzychenko \& Liesch, 2015). Increasing competition in the garment market, opportunity identification is emerging as an important capability that can be developed as industrial competitiveness. Thirdly, the quick response and risk identification are proposed as main factor in market based view which can provide the customer with diverse services and allow industry survive from market risk. The emphasis of the quick response is fast communicate with customer and enable industry to increase response to change in product demand rapidly in the global market (Schary et al., 2001). Therefore, the quick response is important term for both information systems and logistics. Risk identification is the process of risk management that could prevent the industry from the potential risk to achieving its objectives (Dinu, 2012). This process predicts the emergence of negative events which will cause loss or forecasts positive events which bring sector benefit. It also helps industry improve its competitiveness.

\subsection{Agile Supply Chain}

According to Goldman (1995), from business perspective, agility is defined as a business ability that is more flexibility in a changeable market place, where this ability is totally to require driven. The elemental driven of agile supply chain are speed, cost and efficiency, therefore, agile supply chain framework is consist of four major factors including virtual integration, process alignment, network based and Market sensitive (Christoper, 2005). Achiving agile supply chain relies on other capabilities; including responsiveness and quickness (Mehralian et al., 2015). Market sensitive allow the supply chain is able to identify the real demand from the market. In present time, organizations are capable to acquire data from daily Point of sale (POS) which allow company capture the emerging trend by taking feedback from daily sale, Therefore, the organization can control the inventory and respond directly to it. The end consumer's feedback is the driver of the supply chain. There are no boundaries in supply chain like this. About network based, all actors in the supply chain are coordinators, they equally own the chain. Every individual actor in the supply chain must to endeavor to make good performance. Agile supply chain has been recognized as the solution to improve the responsiveness in changeable market. Today's supply chain face to various challenges, but the most organization adopted agile supply chain since it has enhanced the suppliers to manage their own data, such as Zara and UNIQLO's supply chain, are successful global fashion retailers.

Scholars have summarized the industrial competitiveness related factors theoretical frameworks which generally contain resource-based, dynamic capabilities and market-based.This research concerns about what specific factors affect the competitiveness in EOG industry. Research showed the export growth is able to totally reflect the competitiveness of industry. Based on this, the quantitative approach was conducted to this research which the export growth (proxy of competitiveness) was taken as the dependent variable. Combing the garment global value chain and industrial competitiveness models, the productivity, the lead-time, Collaboration, opportunity identification, quick response and risk identification were regarded as the principal factor of independent variable. The following hypotheses about the relation between dependent and independent variable were 
proposed, shown in Figure 1.

H1: The export growth of EOG sector is positively related to Resource-based factors.

H1a: The export growth of EOG sector is positively related to the productivity.

H1b: The export growth of EOG sector is positively related to shorten the lead- time.

H2: Dynamic capabilities factors affect the export growth of EOG sector.

H2a: Collaboration in supply chain affects the export growth of EOG sector.

$\mathrm{H} 2 \mathrm{~b}$ : The capability of opportunity identification affects the export growth of EOG sector.

H3: The export growth of EOG sector is positively related to Market-based factors.

H3a: The export growth of EOG sector is positively related to the sector's ability of quick response in market.

H3b: The export growth of EOG sector is positively related to the sector's ability of risk identification in market.

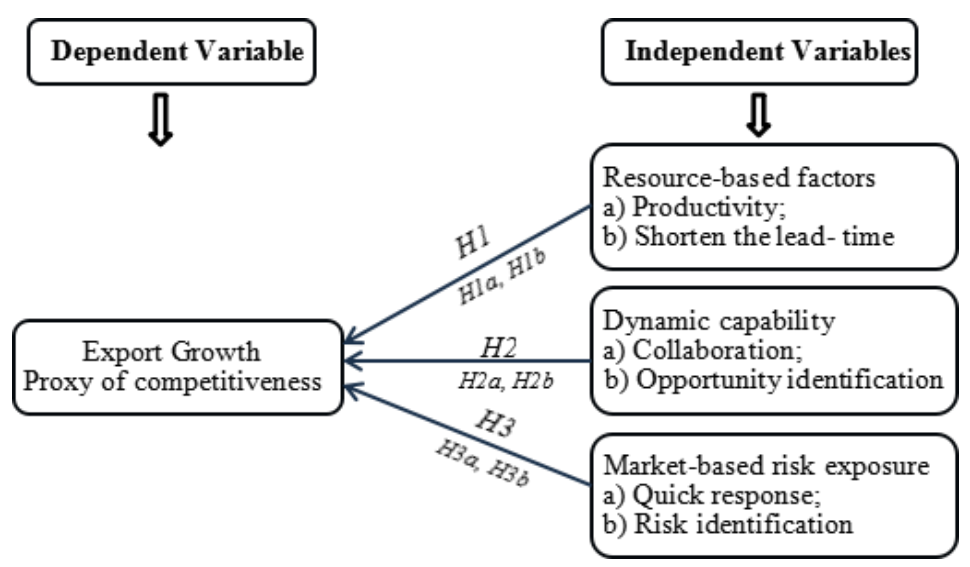

Figure 1. Hypotheses

Source: Developed by Researcher

\section{Methodology}

Finding and retaining competitiveness may allow an organization to meet export-oriented garment industry challenges as well as help understanding sector's upgrading capabilities. Therefore, research need to identify the competitiveness challenge that the industry faces. This study utilizes the quantitative approach for testing the hypotheses which are assumed base on the literature review. The author conducted quantitative approach for all the hypotheses and constructed a questionnaire, and then determined results consequently. The simple, direct, clear and concise language was used in questionnaires and ensured anyone can understand the questions, and occasionally the questions have to be translated into a language which the respondents are more familiar and easy. Respondents are invited to answer the anonymous questionnaires that contain no identifying information are more likely to generate truthful response.

\subsection{Population and Sample Sizes}

Sampling is the use of adequate sample size which can estimate results for the whole population with a good precision (Cochra, 1977; Singh \& Chaudhury, 1985). In other word, researcher has to generalize about the population from the sample data because it is almost impossible randomly sample the entire population. The target population of this research was the managers who actively worked and are currently working in EOG industry for management. They are among the policy maker, executives, and others relevant stakeholders who might play important roles on the decision. It was necessary to select managers in EOG sectors, especially for those who take charge of the decision. As this study investigated the management in EOG sectors, the total number of supervisors and managers in the sectors ( $\mathrm{N}=359$ persons) represent the target population (GMA.2012). 


$$
\begin{gathered}
n=\frac{N}{1+N(\boldsymbol{e})^{2}} \\
n=\text { Number of Sample size } \\
N=\text { Number of Population size } \\
e=\text { the error } 5 \text { percentage points }
\end{gathered}
$$

To calculate the population sample size with an error 5\% and with a confidence coefficient of $95 \%$ in this study by using the Yamame formula. Equation, and then the result came up with be a sample size of about 199 participants. That mean the sample size was at least 199 persons, the structured questionnaires were distributed to 250 persons and there was a received back 211 pieces. A total of 211 respondents fully answered the required questions. It was a responded rate of $84.4 \%$. Returned questionnaires were analyzed for any sound in the responses and then entered into the SPSS spreadsheet, this was then double-checked for any invalids that there was an overall reliability. It was determined that there was an overall reliability value of 0.977 , caculated by the Cronbach's Alpha method, which is above the acceptable minimum value of 0,70 (Zikmund, 2000).

\subsection{Research Instruments}

The opinion-based questionnaires were involves close questions. The questionnaires for the EOG industry include three main parts. The variables are divided into 3 broad categories related to resource-based, capabilities and market-based risk exposure. The principle goal factor of industrial competitiveness was defined in first section as the export growth which is the proxy of competitiveness. The impact factors of competitiveness were represented by the six indicators:

1) Resource-based. a) Productivity; b) Shorten the lead-time,

2) Dynamic capability. c) Collaboration; d) Capability of opportunity identification,

3) Market-based risk exposure. e) Ability of quick response in market; f) Ability of risk identification in market

In this study the principle goal factor of industrial competitiveness was operationalized as export growth of EOG industry. This limitation is dictated by two reasons. First, there is a great technical difficulty to measure the industry resource level because some of factors are intangible asset. Second, dynamic capabilities can't calculated by the difference data. To identify the relationship between export growth and the influence factors of industrial competitiveness, export growth was calculated as follows to properly represent positive and negative growth of value. For Likert (1932) Scales, the key to successful attitude measurement was to convey this underlying dimension to survey respondents, so that they could select the response option that best reflects their opinion in the questionnaire.

In order to be able to use statistics that assume the variable is interval. In the finding section, these results were adapted according to the class interval method described by Lind et al (2003). While construction of frequency distribution the class first we determine $\mathrm{k}$ number of classes then width can be determined by using following formula.

$$
\begin{aligned}
w & =\text { Class Width } \\
& =\frac{\text { Largest observation-Smallest observation }}{\text { Number of Classes }}
\end{aligned}
$$

Consequently, results of data analysis regarding each variable were defined as in table below result.

Table 1. Interpretation of measurement result

\begin{tabular}{cc}
\hline Result & Interpretation \\
\hline $4.21-5.00$ & Strongly Agreed \\
$3.41-4.20$ & Agreed \\
$2.61-3.40$ & Neutral \\
$1.81-2.60$ & Disagreed \\
$1.00-1.80$ & Strongly Disagreed \\
\hline
\end{tabular}




\subsection{Data Collection}

Out of 250 questionnaires distributed to the EOG industries during the survey, 211 pieces were returned which shows $84.4 \%$ of response rate. Help in distributing and collecting the questionnaires under the help of SMEs exporter association, Garment Manufacturers Association (GMA) and Chinese company which have business in global market. However, official letters were always used to seek permission from the relevant organization together with the questionnaires. The survey questionnaires were distributed among EOG sectors via E-mail from March 2018 in Thailand. The goal of the data collection is to find out how the relationship among between resource-based, capabilities, market risk exposure in EOG sectors. This should also be the goal of the questions. The questions were designed to be as short as possible in order to keep up the respondents' interest and ensure reliable answers and to save time in analyzing the results at the same time to be comprehensive and collect all necessary information.

\subsection{Data Analysis}

\subsubsection{Variable Value Measurement with Frequency Distribution}

Variable measurement can specify the level of measurement as scale that can take on a number of particular values, with different value possible for each instance. The group of variables that can be describes the nature of information by the position of a single point on some particular scale.

Table 2. Measurement with frequency distribution by resourced-based factors

\begin{tabular}{lcccc}
\hline Variables & $\begin{array}{c}\text { Frequency } \\
\overline{\mathrm{x}}\end{array}$ & SD & Level \\
\hline $\begin{array}{l}\text { I: Resourced-based Factors } \\
\text { A-1 Time schedule of manufacturing positively influence export growth }\end{array}$ & 4.13 & 1.008 & Agreed \\
A-2 Suitable production management system relate to export growth & 4.36 & .874 & Agreed \\
A-3 Skilled workforce improve export growth & 4.29 & .762 & Strongly Agreed \\
A-4 Equipment upgrading is able to earn more order & 4.27 & .834 & Strongly Agreed \\
A-5 Quality control system benefits for export growth & 4.43 & .861 & Strongly Agreed \\
A-6 Reliability of delivery is able to earn more order & 4.22 & .874 & Strongly Agreed \\
A-7 Eliminating loss time and off-standard time & 4.14 & .850 & Agreed \\
\hline
\end{tabular}

The results from Table 2 part I: Resourced-based Factors revealed that the respondents agreed that "A-1: Time schedule of manufacturing positively influence export growth" $(\overline{\mathrm{x}}=4.13, \mathrm{SD}=1.008)$. Respondents agreed with "A-2 Suitable production management system relate to export growth" $(\overline{\mathrm{x}}=4.36, \mathrm{SD}=0.874)$, "A-3 Skilled workforce improve export growth" strongly agreed $(\overline{\mathrm{x}}=4.29, \mathrm{SD}=0.762)$, "A-4 Equipment upgrading is able to earn more order" strongly agreed $(\overline{\mathrm{x}}=4.27, \mathrm{SD}=0.834)$, the respondents strongly agreed that "A-5 Quality control system benefits for export growth" ( $\overline{\mathrm{x}}=4.43, \mathrm{SD}=0.861)$ and "A-6 Reliability of delivery is able to earn more order" ( $\overline{\mathrm{x}}=4.22, \mathrm{SD}=0.874)$, Respondents agreed with" A-7 Eliminating loss time and off-standard time can increase export growth" ( $\overline{\mathrm{x}}=4.14, \mathrm{SD}=0.850)$. Resourced-based factors by 7 questions with an overall mean result of $\bar{x}=4.26, S D=0.866$. The scores fell in a range from 4.13-4.43, which leads to the conclusion that resourced-based factors do have some influence on export growth. The most results revealed that the respondents agreed or strongly agreed. The results in this section commonly indicated resourced-based factors have some influence on export growth. 
Table 3. Measurement with frequency distribution by dynamic capabilities factors

\begin{tabular}{llll}
\hline Variables & \multicolumn{2}{c}{ Frequency } & \\
& $\mathrm{x}$ & $\mathrm{SD}$ & Level \\
\hline II: Dynamic Capabilities Factors & & & Agreed \\
B-1 Multiple marketing channels are able to improve export growth 4.07 & .814 & .808 & Agreed \\
B-2 Out-sourcing ability enhances export growth & 4.01 & .808 & Agreed \\
B-3 Information system benefit for export growth & 3.91 & .681 & Strongly Agreed \\
B-4 Higher value-added services enable to earn more purchase order4.36 & .831 &
\end{tabular}

The result from Table 3 part II : Dynamic Capabilities Factors revealed that the respondents agreed that "B-1 Multiple marketing channels are able to improve export growth" $(\overline{\mathrm{x}}=4.07, \mathrm{SD}=.814)$, "B-2 Out-sourcing ability enhances export growth" agreed $(\overline{\mathrm{x}}=4.01, \mathrm{SD}=.808)$, "B-3 Information system benefit for export growth" agreed with $(\overline{\mathrm{x}}=3.91, \mathrm{SD}=.681)$, and "B-4 Higher value-added services enable to earn more purchase order" agreed with $(\overline{\mathrm{x}}=4.36, \mathrm{SD}=.831)$. Dynamic Capabilities Factors by 4 questions with an overall mean result of $\overline{\mathrm{x}}=$ $4.09, \mathrm{SD}=0.79$. The scores fell in a range from 3.91-4.36, which leads to the conclusion that dynamic capabilities factors dose have some influence on export growth. The most results revealed that the respondents agreed. The results in this section commonly indicated have some influence on export growth.

Table 4. Measurement with frequency distribution by market-based factors

\begin{tabular}{|c|c|c|c|}
\hline \multirow{2}{*}{ Variables } & \multicolumn{3}{|c|}{ Frequency } \\
\hline & $\bar{x}$ & SD & Level \\
\hline \multicolumn{4}{|l|}{ III: Market-based Factors } \\
\hline C-1 Non-standardized process reduces export growth & 4.57 & .833 & Strongly Agreed \\
\hline C-2 Decision making system helps to increase export growth & 4.55 & .889 & Strongly Agreed \\
\hline $\begin{array}{l}\text { C-3 Difficult to survive from economic downturn will reduce export } \\
\text { growth }\end{array}$ & 4.50 & .819 & Strongly Agreed \\
\hline C-4 Late customer payments higher impacts the export growth & 4.41 & .881 & Strongly Agreed \\
\hline
\end{tabular}

The results from Table 4 partIII: Market-based Factors revealed that the respondents strongly agreed with " $\mathrm{C}-1$ Non-standardized process reduces export growth" ( $\overline{\mathrm{x}}=4.57, \mathrm{SD}=0.833)$, and "C-2 Decision making system helps to increase export growth" ( $\overline{\mathrm{x}}=4.55, \mathrm{SD}=0.889)$, the respondents strongly agreed that "C-3 Difficult to survive from economic downturn will reduce export growth" $(\overline{\mathrm{x}}=4.50, \mathrm{SD}=0.819)$, and "C-4 Late customer payments higher impacts the export growth" ( $(\overline{\mathrm{x}}=4.41, \mathrm{SD}=0.881)$. This result confirmed that the respondents were highly positive response to all issues. Market-based factors by 4 questions with an overall mean result of $\overline{\mathrm{x}}$ $=4.51, \mathrm{SD}=0.858$. The scores fell in a range from 4.41-4.57, which leads to the conclusion that market-based factors dose have some influence on export growth. The most results revealed that the respondents strongly agreed. The results in this section commonly indicated have some influence on export growth.

\subsubsection{Hypotheses Testing Methods}

The process of distinguishing between the null hypothesis and the alternative hypothesis is aided by specifying parametric limits.

Testing hypothesis.

H1: The export growth of EOG sector is positively related to Resource-based factor (H1a.Productivity, H1b. 
Shorten the lead- time).

H2: Dynamic capabilities factor (H2a. Collaboration in supply chain, H2b. Capability of opportunity identification) affect the export growth of EOG sector.

H3: The export growth of EOG sector is positively related to Market-based factor (H3a. Ability of quick response, $\mathrm{H} 3 \mathrm{~b}$. Ability of risk identification).

Due to the large number of variables involved in each hypothesis, factor analysis was used to describe the significant relationship between above observed variables and export growth of EOG sector. The observed variables were analyzed using principal component analysis with Varimax rotation, which can reduce the data dimensionality. The factor analysis of export growth was to examine and compare the interpretable and meaningful factors that influence the export growth in EOG industry. The exploratory factor analysis method was conducted to uncover the underlying structure of 15 variable of competitiveness challenges survey. The factor analysis is often used in data reduction to identify small group of factors that interpret the observed variables with the strongest relationship. Therefore, this section carried out the principal component analysis and rotation methods in order to examine which of the loadings are significant to the study. This factor analysis application also attempts to examine whether any new factors were generated, which are significant and easier to be interpreted. However, in order to make the factor analysis procedure more obvious, many applicable statistical conditions are needed to support the satisfied and reliable results before identifying the potential variable of competitiveness challenges. All items were factor analyzed using principal component analysis followed by Varimax rotation

\section{Validity and reliability.}

1) Validity The validity of research data was tested by using SPSS the KMO statistic and Barlett's test for sphericity, the result is shown on below Table 5 .

Table 5. Value of KMO and Barlett's test variable that affect the export growth

\begin{tabular}{|c|c|c|}
\hline \multicolumn{2}{|c|}{ Kaiser-Meyer-Olkin Measure of Sampling Adequacy.(KMO) } & .866 \\
\hline \multirow{3}{*}{ Bartlett's Test of Sphericity } & Approx. Chi-Square & 3392.274 \\
\hline & df & 105 \\
\hline & Sig. & .000 \\
\hline
\end{tabular}

2) Reliability The data of questionnaire was input into SPSS software, test by Cronbach's a, the result is as below Table 6 .

Table 6. Reliability statistic

\begin{tabular}{ccc}
\hline Cronbach's Alpha & Cronbach's Alpha Based on & N of Items \\
\hline .948 & .948 & 15 \\
\hline
\end{tabular}

After testing the validity, the reliability of the questionnaires were analyzed for any invalid data in the response and then entered into the SPSS spreadsheet, and then, the results were submitted to tests for reliability. According to the Table 6, it was determined that there was an overall reliability of 0.984 , calculated by the Cronbach's Alpha, which is above the acceptable minimum value of 0.70 (Zikmund, 2000), so this Liker scale have higher reliability and stability. The factors have been identified with reference to their real values. Table 7 presents the communalities of the initial variable, pieces of variables explained using common factors. 
Table 7. The main results of factor analysis: communalities

\begin{tabular}{llll}
\hline \multicolumn{1}{c}{ Variables } & Initial & Extraction \\
\hline A-1 Time schedule of manufacturing positively influence export growth & 1.000 & .626 \\
& & \\
A-2 Suitable production management system relate to export growth & 1.000 & .755 \\
A-3 Skilled workforce improve export growth & 1.000 & .859 \\
A-4 Equipment upgrading is able to earn more order & 1.000 & .851 \\
A-5 Quality control system benefits for export growth & 1.000 & .827 \\
A-6 Reliability of delivery is able to earn more order & 1.000 & .834 \\
A-7 Eliminating loss time and off-standard time can increase export growth & 1.000 & .862 \\
B-1 Multiple marketing channels are able to improve export growth & 1.000 & .815 \\
B-2 Out-sourcing ability enhances export growth & 1.000 & .739 \\
B-3 Information system benefit for export growth & 1.000 & .775 \\
B-4 Higher value-added services enable to earn more purchase order & 1.000 & .595 \\
C-1 Non-standardized process reduces export growth & 1.000 & .842 \\
C-2 Decision making system helps to increase export growth & 1.000 & .810 \\
C-3 Difficult to survive from economic downturn will reduce export growth & 1.000 & .756 \\
C-4 Late customer payments higher impacts the export growth & 1.000 & .794 \\
\hline
\end{tabular}

Table 7 shows the selected principal components contain quite a sufficient amount of information about the variable due to the fact that all communalities leaving a correlation between 0.626 and 0.862 . Thus, 15 significant factors which are higher than 1.00 (initial), have been identified to affect the export growth between factors extracted from the previous parameters. The results are presented in Table 8.

Table 8. The number of factors depending on export growth statistics and the percentage of the variance explained

\begin{tabular}{cccc}
\hline \multirow{2}{*}{ Component } & \multicolumn{3}{c}{ Rotation Sums of Squared Loadings } \\
\cline { 2 - 4 } & Total & \% of Variance & Cumulative \% \\
\hline 1 & 8.788 & 58.589 & 58.589 \\
2 & 1.800 & 11.997 & 70.586 \\
3 & 1.151 & 7.675 & 78.261 \\
\hline
\end{tabular}

Table 8 shows that three components related with export growth by Varimax Rotation explain $78.261 \%$ of variance. When analyzing the factors by rotation, the communalities of the variables on export growth of garment sector consist of 3 components.

1) Resource-based factors that can be explained to 58.589 percentage of the variance.

2) Dynamic capabilities factors that can be explained to 11.997 percentage of variance.

3) Market-based factors that can be explained to 7.675 percentage of the variance. 
Therefore, these three components are combined and can be explained by $78.261 \%$ variance.

Table 9. Component 1 (the results of factor analysis considering Resource-based factors)

Variables Resource-based factors

Factor Loading

A-3 Skilled workforce improve export growth

A-4 Equipment upgrading is able to earn more order

C-2 Late customer payments higher impacts the export growth

C-3 Difficult to survive from economic downturn will reduce export growth

A-2 Suitable production management system relate to export growth

C-2 Decision making system helps to increase export growth

A-5 Quality control system benefits for export growth

A-1 Time schedule of manufacturing positively influence export growth

Table 9 shows that component 1 covers 9 variables that affect the resource-based factors in the components are between 0.610 and 0.892 that can be explained by 58.589 percentage of the variance. Therefore, nine variables are commonly described at its best. The variables can explain these clearly including: variable A-3 (Skilled workforce improves export growth), Variable A-4 (Equipment upgrading is able to earn more order) and A-5 (Quality control system benefits for export growth), while variable A-1 (Time schedule of manufacturing positively influence export growth) associated with this component at its minimum. The researcher called this component as resource-based factors.

Table 10. Component 2 (the results of factor analysis considering Dynamic capabilities factors)

Variables Dynamic capabilities factors

Factor Loading

B-3 Information system benefit for export growth

B-2 Out-sourcing ability enhances export growth

B-4 Higher value-added services enable to earn more purchase order .543

Percentage of variance explained by components 11.997 
Table 10, the factor analysis of the variables influencing Dynamic capabilities factors cover three key variables and the weight variables in components between 0.543 and 0.839 that can be explained to 11.997 percentage of the variance. Therefore the three variables can be described at its best. The variables can explain these clearly including: a variable B-3(Information system benefit for export growth), variable B-4 (Higher value-added services enable to earn more purchase order), and B-2 (Out-sourcing ability enhances export growth) subsequently. Therefore the researchers called this component as dynamic capabilities factors.

Table 11. Component 3 (the results of factor analysis considering market-based factors)

Variables $\quad$ Market-based factors

Factor Loading
A-7 Eliminating loss time and off-standard time can increase export growth .892
A-6 Reliability of delivery is able to earn more order
B-1 Multiple marketing channels are able to improve export growth
Percentage of variance explained by components

From the table 11, when analyzing the composition of variables affecting Market-based factors cover33 variables and the weight variable in composition between 0.766 and 0.892 that can be explained to 7.675 percentage of the variance of the three variables described at its best. The variables can explain these clearly including: a variable component A-7 (Eliminating loss time and off-standard time can increase export growth) followed by A-6 (Reliability of delivery is able to earn more order) and variable B-1 Multiple marketing channels are able to improve export growth) Therefore the researchers called this component as market-based factors.

\section{Result of ANOVA test}

Statistically significant deviations in terms of the export growth have been obtained considering component 1 (Resource-based Factors), component 2 (Dynamic Capabilities Factors), component 3 (Market-based factors). One-way ANOVA analysis was used in order to evaluate hypotheses dealing within interval variable with a designated significance level of 0.05 .

Table 12. Relationship between resource-based factors and export growth

\section{Enhance to Export Growth}

\begin{tabular}{lll} 
& $\chi^{2}$ & $\mathbf{P}$ \\
\hline 1. To improve the productivity & 22.258 & $.00^{*}$ \\
2. To shorten the lead-time & 21.614 & $.00^{*}$ \\
3. Collaboration in supply chain & 23.540 & $.00^{*}$ \\
4. The capability of opportunity identification & 25.048 & $.00^{*}$ \\
5. The ability of quick response in market & 22.040 & $.00^{*}$ \\
6. The ability of risk identification in market & 27.638 & $.01^{*}$ \\
\hline
\end{tabular}

\section{Resource-based Factors}

The result of Table12 shows statistically significant deviation regarding the relationship between resource-based factors and exportgrowth. Null hypothesis H (0)1 about the export growth of EOG sector is not relationship with resource-based factors is rejected at the level of significance and makes $\mathrm{p}<0.05$.Therefore, H1, H1a, H1b were accepted, the export growth of EOG sector is positively related to resource-based factors. 
Table 13. Relationship between dynamic capabilities factors and export growth

\begin{tabular}{|c|c|c|}
\hline \multirow{3}{*}{ Enhance to Export Growth } & \multicolumn{2}{|c|}{ Dynamic } \\
\hline & Capabilities & \\
\hline & $\chi^{2}$ & $\mathbf{P}$ \\
\hline 1. To improve the productivity & 26.601 & $.00^{*}$ \\
\hline 2. To shorten the lead-time & 43.737 & $.00^{*}$ \\
\hline 3. Collaboration in supply chain & 42.700 & $.00^{*}$ \\
\hline 4. The capability of opportunity identification & 26.133 & $.00^{*}$ \\
\hline 5. The ability of quick response in market & 20.736 & $.00^{*}$ \\
\hline 6. The ability of risk identification in market & 11.130 & $.001 *$ \\
\hline
\end{tabular}

*Significant at 0.05

The result of Table 13 shows statistically significant deviation regarding the relationship between resource-based factors and export growth. Null hypothesis H (0)2 about the export growth of EOG sector is not relationship with dynamic capabilities factors is rejected at the level of significance and makes $p<0.05$. Therefore, H2, H2a, H2b were accepted, the export growth of EOG sector is positively related to dynamic capabilities factors.

Table 14. Relationship between Market-based factors and Export Growth

\begin{tabular}{lll}
\hline Enhance to Export Growth & Market-based factors & \\
& $\chi^{2}$ & $\mathrm{P}$ \\
\hline 1. To improve the productivity & 25.613 & $.00^{*}$ \\
2. To shorten the lead-time & 13.907 & $.00^{*}$ \\
3. Collaboration in supply chain & 20.756 & $.02^{*}$ \\
4. The capability of opportunity identification & 15.087 & $.00^{*}$ \\
5. The ability of quick response in market & 13.650 & $.00^{*}$ \\
6. The ability of risk identification in market & 20.643 & $.00^{*}$ \\
\hline
\end{tabular}

*Significant at 0.05

The result of Table 14 shows statistically significant deviation regarding the relationship between market-based factors and export growth. Null hypothesis $\mathrm{H}(0) 3$ about the export growth of EOG sector is not relationship with market-based factors is rejected at the level of significance and makes $p<0.05$. Therefore, H3, H3a, H3b were accepted, the export growth of EOG sector is positively related to market-based factors.

\section{Results}

This section presents conceptual model derived from the theoretical underpinnings of the literature review and the result of empirical research by conducting factor analysis as following Figure5. 


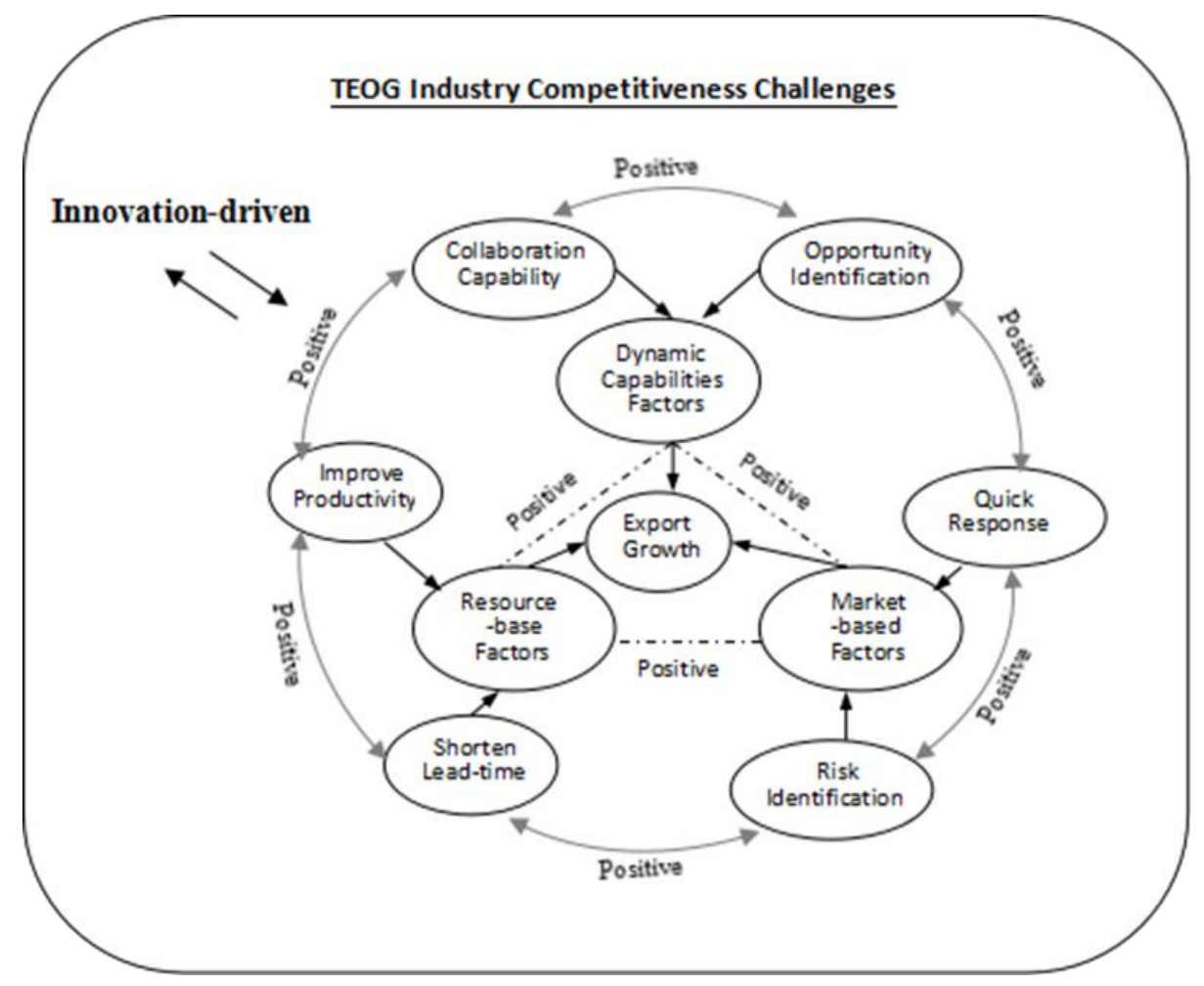

Figure 2. EOG Industry Competitiveness Challenges Model

Source: Developed by Researcher

Figure 2 is a refinement of the industrial competitiveness challenges models. The previous framework are useful for understanding the related theoretical underpinning of EOG industry competitiveness challenges, but it is limited in that it is independent and does not show the specific factors and its dynamic interaction between the elements as dose the model in Figure 2. The EOG industry competitiveness challenges model is a cycle diagram model showing the interactive relationships between the various categories of competitive challenges that The EOG industry encounter (i.e., productivity, lead-time, collaboration, opportunity identification, quick response and risk identification factors). The interaction between a sector's resource-based, dynamic capabilities, and market-based depicted in the EOG industry competitiveness challenges model leads to this dissertation's 1-3 research questions:

Question 1-3: There is: (1) the resource-based factors influence export-oriented garment sector's competitiveness; (2) the dynamic capabilities was demanded by facing competitiveness challenges; (3) the market-based factors were confirmed for overcoming the market risk. Firstly, a positive relationship among three components, enhancing industry's dynamic capabilities and resource-based factors will receive more purchase order in global market. Second, higher collaboration capability is able to improve productivity and shorten lead-time, especially, for small and middle size sectors, opportunity identification allow the EOG sectors to enforce quick response and risk identification in global market. Third, risk identification will generate positive impact both in lead-time and productivity. This model also implicates that the utilization of innovation-driven strategy can potentially enhances the industry's resource-based factors, dynamic capabilities factors and market-based factors. This EOG industry competitiveness challenges model descripts the factors related to resource-based, dynamic capabilities, and market-based as having important roles in an open innovation environment. Participant interviews identified the need for support of innovation-driven through enhancing the industry's resource-based factors, dynamic capabilities factors and market-based factors of EOG industry. Some of international famous buyers such as ZARA, GAP, H\&M, demand very short lead time for keeping its agility and flexibility in retail market. Participant statements detailed the need for managerial innovation when taking risk, one participant stated, "innovation-driven such as data-driven on the process of purchase order follow-up, will be good way improve the efficient and reduce mistake and produce cost" Another statement indicated to the enforcement of collaboration also can foster competitive advantage with innovation-driven. This description suggests that successful utilization of innovation-driven strategy can potentially enhance the garment sector's competitiveness. 


\section{Conclusions}

The finding of this study can be understood as survey of exported-oriented garment industry in Thailand. The purpose of this study has presents whether these three factors have positive significant impact on the export growth. The participants of this study were all those management in EOG industry. The structured questionnaires were distributed to 250 sectors and a total of 211 respondents fully answered the required questions.

\subsection{Discussion and Implication}

The result implicates that the innovation-driven is urgently needed to overcoming competitiveness challenges in this industry. Emphasis of the need for innovation-driven in EOG industry is not simply improve management skill in sectors only, both supply chain and demand value chain should be considered. Discussed with participants and highlighted the competitive challenges the garment industry encounters, have stimulated the senior managers concerning more about the concept of innovation-driven. Call for innovation-driven, maybe it is crucial need for EOG industry overcoming competitive challenges in the context of situation. No similar model exists, but Watchravesringkan et al. (2010) found the sophisticated demanding consumer market, interdependent economic agents and strategies were determinants supporting competitiveness of EOG industry. Additionally, Hideki Esho (2015) claims that EOG industry can develop it competitiveness in terms of enhancing merchandizing, marketing and coordinating capabilities and skills. This study provides something new in the scholarship in competitiveness challenges of export-oriented garment industry, particularly a new explanation of competitiveness challenges model. The new model offers new possibility to the garment managers searching to focus on key factors to develop sector competitiveness. The factors identified offer new information to consider in developing the competitive advantage of garment industry. The results of this study indicate only in the Thailand export-oriented garment industry. The same association was not confirmed for the other industry examined in the study. It is important to further investigation how the export-oriented garment competitiveness in other developing economy is affected by same factors.

\subsection{Research Limitations}

It is important that the limitations of the study are identified in order to benefit for further research. There are two limitations should be considered, firstly, the research design did not include customers' perspective with demanding side. The research sample was purposeful position in order to obtain biased perspective from manager's professional experience, thus exploring a field not previously researched. Secondly, regarding the limitation of the sample size, it would bias the results of overall analyses toward the null hypothesis. Therefore, it is difficult to avoid the sources of potential bias in the interpretation of research results.

\section{References}

Cavana, R. Y., Delahaye, B. L., \& Sekaran, U. (2001). Applied business research: Qualitative and quantitative methods. John Wiley \& Sons Australia.

Chan, M. L., \& Mountain, D. C. (1983). Economies of scale and the Tornqvist discrete measure of productivity growth. The Review of Economics and Statistics, 663-667. https://doi.org/10.2307/1935938

Chien, S. Y., \& Tsai, C. H. (2012). Dynamic capability, knowledge, learning, and firm performance. Journal of Organizational Change Management. https://doi.org/10.1108/09534811211228148

Chowdhury, M. M. H., \& Quaddus, M. (2017). Supply chain resilience: Conceptualization and scale development using dynamic capability theory. International Journal of Production Economics, 188, 185-204. https://doi.org/10.1016/j.ijpe.2017.03.020

Christopher, M., \& Towill, D. R. (2005). Developing market-specific supply chain strategies. The International Journal of Logistics Management, 13(1), 1-14. https://doi.org/10.1108/09574090210806324

Cochran, W. G. (1977). Sampling Techniques (3rd ed.). New York: Wiley.

Curwen, L. G., Park, J., \& Sarkar, A. K. (2013). Challenges and solutions of sustainable apparel product development: A case study of Eileen Fisher. Clothing and Textiles Research Journal, 31(1), 32-47. https://doi.org/10.1177/0887302X12472724

Dinu, A. M. (2012). Modern methods of risk identification in risk management. International journal of academic research in economics and management sciences, 1(6), 67.

Esho, H. (2015). Dynamics of the Textiles \& Apparel Industries in Southeast Asia. Journal of International Economic Studies, 14(29), 85-106.

Hunt, S. D., \& Davis, D. F. (2012). Grounding supply chain management in resource - advantage theory: In 
defense of a resource - based view of the firm. Journal of Supply Chain Management, 48(2), 14-20. https://doi.org/10.1111/j.1745-493X.2012.03266.x

Kozlenkova, I. V., Samaha, S. A., \& Palmatier, R. W. (2014). Resource-based theory in marketing. Journal of the Academy of Marketing Science, 42(1), 1-21. https://doi.org/10.1007/s11747-013-0336-7

Likert, R. (1932). A technique for the measurement of attitudes. Archives of psychology.

Lind, L. (2003). Circulating markers of inflammation and atherosclerosis. Atherosclerosis, 169(2), 203-214. https://doi.org/10.1016/S0021-9150(03)00012-1

Lockett, A., Thompson, S., \& Morgenstern, U. (2009). The development of the resource - based view of the firm: A critical appraisal. International journal of management reviews, 11(1), 9-28. https://doi.org/10.1111/j.1468-2370.2008.00252.x

Matopoulos, A., Vlachopoulou, M., Manthou, V., \& Manos, B. (2007). A conceptual framework for supply chain collaboration: empirical evidence from the agri-food industry. Supply Chain Management: an international journal, 12(3), 177-186. https://doi.org/10.1108/13598540710742491

Muzychenko, O., \& Liesch, P. W. (2015). International opportunity identification in the internationalisation of the firm. Journal of World Business, 50(4), 704-717. https://doi.org/10.1016/j.jwb.2014.12.001

Singh, R. K., \& Chaudhury, B. D. (1985). Biometrical 14. Baisakh, B., BK Mohapatra and RC Misra, 1989. methods in quantitative genetic analysis.

Ushiyama, R., \& Towill, D. R. (2005). Textile trade liberation: concerns about widening gaps among ASEAN nations. JCER Research Report, 52(2), 41-74.

Utami, R. M., \& Lantu, D. C. (2014). Development competitiveness model for small-medium enterprises among the creative industry in bandung. Procedia-Social and Behavioral Sciences, 115(21), 305-323. https://doi.org/10.1016/j.sbspro.2014.02.438

Vlachvei, A., \& Notta, O. (2017). Firm Competitiveness: Theories, Evidence, and Measurement. In Factors Affecting Firm Competitiveness and Performance in the Modern Business World (pp. 1-42). IGI Global. https://doi.org/10.4018/978-1-5225-0843-4.ch001

Watchravesringkan, K., \& Hodges, N. (2013). Model entrepreneurial career intentions among undergraduates: An examination of the moderating role of entrepreneurial knowledge and skills. Family and Consumer Sciences Research Journal, 41(2), 325-342. https://doi.org/10.1111/fcsr.12014

Weimer, J., \& Pape, J. (1999). A taxonomy of systems of corporate governance. Corporate Governance: An International Review, 7(2), 152-166. https://doi.org/10.1111/1467-8683.00143

Wernerfelt, B. (1984). A Resource-based View of the Firm. Strategic Management Journal, 5(10), 171-180. https://doi.org/10.1002/smj.4250050207

Wyse, R., Campbell, E., Nathan, N., \& Wolfenden, L. (2011). Associations between characteristics of the home food environment and fruit and vegetable intake in preschool children: a cross-sectional study. BMC public health, 11(1), 938. https://doi.org/10.1186/1471-2458-11-938

Zhang, P., \& London, K. (2013). Towards an internationalized sustainable industrial competitiveness model. Competitiveness Review: An International Business Journal. https://doi.org/10.1108/10595421311305325

Zikmund, W. G., McLeod, R., \& Gilbert, F. W. (2003). Customer relationship management: Integrating marketing strategy and information technology. Wiley.

\section{Copyrights}

Copyright for this article is retained by the author(s), with first publication rights granted to the journal.

This is an open-access article distributed under the terms and conditions of the Creative Commons Attribution license (http://creativecommons.org/licenses/by/4.0/). 